\title{
A tandem journey through the labyrinth
}

\author{
Marcia B. Baxter Magolda \\ Miami University, USA
}

\section{Introduction}

Good company is beneficial on any journey, particularly in complex journeys. Higher education is a complex journey in which learners refine their purpose, establish a vision for their lives, question long-held assumptions, and construct more complex ways of making meaning of knowledge, themselves, and their relations with others. To be good company, educators must balance providing appropriate guidance with empowering learners to direct their own learning journeys. I have used a tandem bicycle metaphor to describe the learning partnerships that help learners move toward self-authoring their beliefs, values, identities and social relations (Baxter Magolda, 2001, 2009). Educators take the back seat of the bicycle to fulfill the stoker role - to help provide the pedaling power needed to propel the bicycle forward. Learners take the front captain's seat to direct the journey. Learners and educators share authority and expertise in this mutual journey such that the learner is able to achieve the interdependence required to succeed in adult life.

Good company varies, however, with the characteristics of learners. My 23-year longitudinal study of young adult learning and development from age 18 to 40 revealed three overarching phases of meaning making (Baxter Magolda, 1992, 2001, 2009). During college most participants relied uncritically on external authorities for what to believe, following external formulas. Near the end of college and in the early years after graduation, they found themselves in a crossroads where their own growing internal voices were in tension with external influences. In their late twenties and in their thirties, most participants gained confidence in their internal voices and brought them to the foreground to coordinate external influence in forming their belief systems and identity. This latter phase is often called selfauthorship (Baxter Magolda, 2001, 2009; Kegan, 1994) because learners use internal 
criteria for decision-making. For learners who enter college with the assumption that knowledge is certain and obtained from authorities, good company focuses on helping learners realize that multiple perspectives exist. For learners who are beginning to question authority and becoming aware of the need to form their own views, good company helps them learn how to evaluate multiple perspectives. For learners who are beginning to form their own views, good company takes the form of helping them refine their internal beliefs and act consistently on them. Thus the tandem journey is tailored to the meaning making of the learner.

\section{The learning partnerships model}

The Learning Partnerships Model (LPM) (Baxter Magolda, 2004) emerged from over 1000 interviews during my longitudinal study. Annual interviews beginning in the first year of college and continuing into participants' adult lives focused on their learning experiences, how they made meaning of knowledge, identity and relationships, and the characteristics of environments that promoted their learning and development. Experiences in college, graduate and professional schools, and employment yielded the key characteristics of learning partnerships that promote development from uncritical acceptance of external authority to self-authorship, or the internal construction of beliefs, values, and identity. Although participants possessed diverse personal characteristics, and experiences spanned numerous contexts, six dynamics emerged that combine to promote learning and self-authorship. Learning partners supported participants in developing self-authorship in three ways:

- Respecting their thoughts and feelings, thus affirming the value of their voices;

- Helping them view their experiences as opportunities for learning and growth, and;

- Collaborating with them to analyze their own problems, engaging in mutual learning with them. (Baxter Magolda, 2009: 251)

These supportive functions helped participants recognise the value of and strengthen their internal voices. Learning partners also challenged participants to develop self-authorship in three ways: 
- Drawing participants' attention to the complexity of their work and life decisions, and discouraging simplistic solutions;

- Encouraging participants to develop their personal authority by listening to their own voices in determining how to live their lives, and;

- Encouraging participants to share authority and expertise, and work interdependently with others to solve mutual problems. (Baxter Magolda, 2009: 251)

This good company enabled learners to see the complexity of knowledge, recognise that they needed to bring their own internal voices to knowledge construction, and see the importance of interdependent collaboration with others to make wise decisions and create new knowledge. They were supported in learning how to become full participants in knowledge construction, work through their own dilemmas, and build interdependent relationships.

\section{Developmentally sequenced learning partnerships}

Learning partnerships, by virtue of respecting learners' voices and experiences, link learning to learners' meaning making capacities. Taylor and Haynes (2008) explicitly articulate the details of what partnerships look like for learners who follow external authority uncritically, who are in a crossroads marked by tension between external voices and their internal voice, and who are coming to trust their internal voices. The resulting three-tiered framework identifies the developmental goals appropriate to each way of making meaning, the learning outcomes for each tier, and how partners would function to provide good company for learners at each tier.

The first tier is designed for learners who tend to view knowledge as absolute, have a limited vision of themselves as legitimate authors of new knowledge, and thus rely uncritically on external authorities for guidance and approval. The developmental goals for this tier include learning to question how authorities construct knowledge, beginning to see the need to create one's own knowledge, and awareness of the limitations of focusing on others' views and approval. Learning goals in this tier centre around identifying multiple perspectives and interacting with others to encounter multiple perspectives. Partners offer good company by 
providing multiple valid perspectives, sequencing material to cultivate learners' discoveryoriented skills, modeling self-reflection, building on students' experiences and voices, and creating a safe climate for dialogue. As a result, learners are challenged to view knowledge as more complicated than they originally assumed, yet they are supported in learning the processes of exploring multiple perspectives.

Tier 2 is designed for learners in the crossroads. These learners are already aware of the uncertainty of knowledge and the need to develop their own views and values. Thus appropriate developmental goals include beginning to choose their own beliefs, learn to decide based on evaluating multiple perspectives, define their own values, and mutually negotiate their perspectives with others. Corollary learning goals include analysing or comparing concepts and frameworks, assessing and refining one's educational goals, and working effectively with diverse others in problem solving. Good company in Tier 2 involves challenging learners to see the limitations and benefits of various knowledge domains, helping learners process problems and discover solutions, and providing opportunities for discovery, connections among learning experiences, and effective teamwork. The primary emphasis here is on supporting learners to trust their own voices and learn processes for evaluating knowledge claims and working in mutual relationships.

Tier 3 is designed for learners who are developing self-authored meaning making to create their internal belief systems and interdependent relations with others. Because they have already concluded that knowledge is complex and contextual and have begun to establish their own beliefs, the development goals for them include acting consistently on their internal belief systems and integrating various aspects of their identities. Accompanying learning goals focus on evaluating and integrating diverse perspectives; creating, critiquing and applying knowledge in multiple contexts; aligning actions and values, and developing a commitment to an inclusive community. Partners offer good company through opportunities for learners to learn from and teach each other, to participate in constructive dialogues around difference, and to construct knowledge. These partnerships help learners refine their belief systems and values and strengthen the capacity to sustain interdependent relationships with diverse others. 


\section{Learning to ride on the back}

Developmentally sequenced partnerships are sometimes challenging for educators because educators are socialised to take charge of the learning journey. Although educators must take more responsibility at the start of the journey, learners must be invited to take increasing responsibility as the journey continues. Learners are introduced to responsibility through learning environments that promote active engagement in Tier 1, invited to co-design learning experiences with educators in Tier 2, and guided by educators to design their own learning in Tier 3. Thus educators must share authority with learners throughout the journey, emphasising that learners are ultimately responsible for their own learning. Numerous reflections about the challenges of this tandem journey are available from educators who have implemented the Learning Partnerships Model in diverse contexts (Baxter Magolda and King, 2004; Meszaros, 2007; Pizzolato and Ozaki, 2007). Yet their stories about learner outcomes suggest that rethinking our roles to invite learners into a mutual partnership benefits us all.

\section{References}

Baxter Magolda, M. B. (1992) Knowing and reasoning in college: gender-related patterns in students' intellectual development. San Francisco: Jossey-Bass.

Baxter Magolda, M. B. (2001) Making their own way: narratives for transforming higher education to promote self-development. Sterling, VA: Stylus.

Baxter Magolda, M. B. (2004) 'Learning Partnerships Model: a framework for promoting selfauthorship', pp. 37-62, in Baxter Magolda, M.B. and King, P.M. (eds.) Learning partnerships: theory and models of practice to educate for self-authorship. Sterling, VA: Stylus.

Baxter Magolda, M. B. (2009) Authoring your life: developing an internal voice to navigate life's challenges. Sterling, VA: Stylus. 
Baxter Magolda, M. B. and King, P. M. (eds.) (2004) Learning partnerships: theory and models of practice to educate for self-authorship. Sterling, VA: Stylus.

Kegan, R. (1994) In over our heads: the mental demands of modern life. Cambridge, Massachusetts: Harvard University Press.

Meszaros, P. S. (ed.) (2007) Self-authorship: advancing students' intellectual growth. New directions for teaching and learning, (Vol. 109). San Francisco: Jossey-Bass.

Pizzolato, J. E. and Ozaki, C. C. (2007) 'Moving toward self-authorship: investigating outcomes of learning partnerships', Journal of College Student Development 48(2) pp 196-214.

Taylor, K. B. and Haynes, C. (2008) 'A framework for intentionally fostering student learning', About Campus: Enriching the Student Learning Experience 13(5) pp 2-11.

\section{Author details}

Marcia Baxter Magolda is Distinguished Professor, Educational Leadership, Miami University. She teaches and advises in the College Student Personnel Master of Science program; Her research includes young adult epistemological development, assessing intellectual development, the role of gender in epistemology, and constructivedevelopmental pedagogy. 